\title{
Effect of Study Circle on Moral Attitudes of Filipino College Students
}

\author{
Pedro S. Cabrales ${ }^{1}$, Mae F. Villanueva ${ }^{2}$, Abigail M. Cabaguing ${ }^{2} \&$ Dennis G. Cosmod ${ }^{3}$ \\ ${ }^{1}$ Department of Social Sciences, College of Arts and Sciences, Samar State University, Philippines \\ ${ }^{2}$ Department of Psychology, College of Arts and Sciences, Samar State University, Philippines \\ ${ }^{3}$ Department of Natural Science, College of Arts and Sciences, Samar State University, Philippines \\ Correspondence: Pedro S. Cabrales, Department of Social Sciences, College of Arts and Sciences, Samar State \\ University, Catbalogan City, Samar, Philippines. Tel: 63-55-251-2139; E-mail: petercabrales@ yahoo.com.
}

Received: August 2, 2013 Accepted: August 22, 2013 Available online: October 21, 2013

doi:10.11114/ijsss.v2i1.192 URL: http://dx.doi.org/10.11114/ijsss.v2i1.192

\begin{abstract}
The study sought to find out the effect of study circle on the moral values of Filipino psychology students of Samar State University, to identify probable external factors, and to develop an improved study circle material to use in this inquiry. The study is anchored on the interrelated theories of cognitive, affective and social potentials as a way to achieve moral and social learning set forth by Kohlberg, Fraenkel, Raths, and Durkheim that occurs spontaneously within the individual. Utilizing the method of triangulation composed of qualitative and quantitative approaches to research, the study examined the process of participation in religious scripture-based study material resulting in the transformation of the person's moral attitude. The findings revealed that participants in the study circle developed better moral attitudes and perception from moderate to strong moral attitude. It also showed that attendance and profile variates of age, sex, family income, occupation, and religion did not correlate to the moral attitude level of the respondents. This implied that participation in the study circle and the usage of the study material were the only factors that caused the significant difference in the mean score, and consequently, the leveling up of participants' moral attitude. The number of participants in the discussions and activities from start to the last session improved from few to almost all, and the qualitative data generated through focus group discussion (FGD) and observation revealed highly favorable comments by respondents on various elements of the program.
\end{abstract}

Keywords: study circle, group learning, moral attitude, religious scriptural study, values education

\section{Introduction}

Cultural decline, opines Schaefer (1983: 83) results from people's rejection of shared values and the prevalence of non-obligatory opinions on basic questions of life that comes from the social trends of individualism, rationalism, scientism and teleology of progress (UNESCO, 1999:26). This phenomenon naturally results in the breaking down of social stability, a condition which leads societies into chaos and anarchy. To address this condition Popenoe (1995) asserts that, the concern for common morality becomes essential in society.

In dealing with this challenge in the global scale, the United Nations Educational, Scientific, and Cultural Organization (UNESCO, 1999: 26) made an appeal to all nations to "identify and forge such ethical values and principles into a coherent and dynamic whole adequate to deal with the problems facing humanity".

The teachings of the world's great religious heritage offer a vital force that can address the issue of cultural decline and social stability. Scriptural principles, such as the "golden rule," not only offer moral standards for social behavior, but also provide spiritual guidance for the well-being of every individual (Baha'u'llah, 1990: 200; Hebrews, 4:12; 3 Kings, 2:4). Such is also the concept of "authentic morality," which Hatcher (1998) refers to as the observance of humane relationships among people as, for instance, following Christ's commandment to "love God with all thy heart and thy neighbor as thy self." (Luke, 10:27).

Study circle is considered one of the approaches to the study of religious text. This method provides a direct, analytic and reflective atmosphere that transforms the individual's cognitive learning into his or her affective and social domain (Kohlberg, 1976; Fraenkel, 1977; Raths et al., 1978; and Durkheim, 1961). As such, it can also influence the process of moral transformation in the individual. 
Inasmuch as study circle provides opportunity for sharing of personal ideas and experiences in many aspects of life, it promotes socialization through discussion and valuing of such ideas with others through dialogic encounters. Conversely, study circle improves socialization which regards highly the presence and participation of others, as it enhances relational values reflected in passages under study, and finally develops intellectual skills in the individual, and thus, effecting moral transformation (Figure 1).

Figure 1. Continuum of values and moral transformation

It is along this view that the method of study circle may affect the development of moral values and attitudes of those who participate in it.

\subsection{Review of Literature}

Learning in the cooperative sense relate to situations that are conducted in school (Johnson et al., 1984; Slavin et al., 1985; and Jacobs, G. M., Lee, C, \& Ng, M. 1997). Other learning opportunities come in the form of organizing community service projects usually held outside of the school premises (Conrad \& Hedin, 1977; Newmann \& Rutter, 1983; Keitgaard, 1985). Nevertheless, the latter activities are somehow still connected to the school and therefore sanctioned by their teachers. In these situations students may be inclined to behave in such a way as to merely please or impress their mentors in order to obtain praise, higher grade, or similar token. There remains a doubt whether the students would exercise autonomy in internalizing moral values and attitudes or simply would manifest them for mere display.

Several studies show that cooperative learning can support an environment in which students feel encouraged to take part (Jacobs, G. M., Lee, C, \& Ng, M., 1997), and for the most part, a broad consideration of social interdependence in solving social problems (Johnson \& Johnson, 2009). However, the said studies are silent about those that directly relate to the development of moral values and attitudes of their participants.

Novel strategies in facilitating conversational or dialectic type of learning whether of a short term (Mazen et al., 2000) or long-term and exhaustive type (Baker et al., 2002.) are largely cognitive. However, as dialogue flows from a posteriori cognition, conversational learning would only provide an occasion for intellectual exchange of opinions that are rather personal, subjective or arbitrary. Morality, when approached from this juncture, would recede back to non-obligatory mode and therefore not providing a binding force in social relations among people.

Study circles are a type of small discussion group consisting of between five to ten members, conducted in democratic atmosphere and highly participatory (Leighninger, 1996). Members usually agree to meet several times to explore and learn about a particular social or political issue in a collaborative manner (Brevskolan, 1980), discussions are based on a common reference material, and intended to have action outcomes. (Gibson, 1998: 4).

Study circles maybe typified as religious-spiritual such as the Roman Catholic's Pax Romana Study Circle (2008), the Sai Centres (Study Circles for Divinity, 2001), the Chamiec-Case \& Sherr study (2005), Center for Ignatian Spirituality (2011), and the Ruhi Study Circle (Ruhi Institute, 2011). Using pre-developed modules, these gatherings promote intellectual-spiritual life to develop the attitude of service to others.

Some study circles are organized to provide effective training for health (Barski-Carrow, 1998) and nutrition services (Sotomayor et al., 2007; Westergren \& Hedin, 2010), and in bringing closer together both managers and employees in the workplace (Barski-Carrow, 1998). Still others focus on educating citizenship and civic training (Brophy, 2011; Larsson, S. \& H. Nordvall, 2010). Such is the impact of this kind of group study that it develops a more profound understanding - that "individual persons are not alone in their concerns, and that they can effectively and meaningfully work together to solve local problems" (McCoy, 2005).

Somewhat similar to study circle method is the reading circle which was found to be effective in inculcating values as a feature of classroom instruction (Hussain \& Munshi, 2011), as in reading literature (Hester et al. 1997), and which used modularized quotations with data collected through observations employing video -taping, interview, and written questions, and notes (Nau, 2012).

Some study circles are objective-based, such as those that promote citizenship and democratic life (Brophy, 2001); others concern with relationships and responsibilities towards the community and its institutions and, thus, help integrate spirituality in the workplace (Chamiec-Case \& Sherr, 2005), or address issues on reproductive health among the youth-i.e. unsafe sex (Boron, 2013).

From its Swedish origin in the early part of the $20^{\text {th }}$ century, then transported to the United States, to Australia, 
India, South Africa and elsewhere, study circles have had a great role in engaging people in issues as diverse as empowering and emancipating marginalized groups (Brophy, 2001), promoting race relations, poverty issues, mitigating environmental disasters, cultivating civic consciousness, adult education issues (Bjerkaker, 2003; Brennan \& Brophy, 2010), or "promoting the well-being of humanity" in general (Ruhi Institute, 2011).

The aforementioned studies generated the following observations regarding study circles: some of them utilize materials that touch on moral and spiritual matters; the themes adapt virtues with universal application; and the course programs contain knowledge that address social, political, and economic issues. These studies show that study circles postulate strong impact on the values and attitudes of its participants. It can be noted, however, that the research design, procedure and methods of analysis were, except that of Baker et al. (2002), of the descriptive type. In addition, there is no mention relative to the aspect of the effect of study circle on the moral attitudes of the individual or group using a quasi-experimental pre-test-posttest design. Such a measure is needed in order to establish whether a study circle is significantly effective in bringing about moral transformation in the individual.

This study attempted to identify, describe, evaluate, and examine some new methods of transforming moral attitudes and offer new insights, models, and strategies in conducting one such as the study circle. It would contribute knowledge relative to the importance of study circles as a tool for personal and social development. The result of the study could be used by educational institutions in the development of spiritual and moral virtues amongst their students. It could also be utilized by organizations - whether governmental, non-governmental, or business - to help develop the potentials of their human resource, to make moral decisions and thus enhance positive work attitudes toward their job. The material could also be applied at home for the enrichment of family values and moral discipline of its members.

This study aimed to determine the effect of study circle in the moral attitudes of psychology students at Samar State University. Findings eventually established such a theory and supported the fact that the study circle method of learning could affect the moral and attitudinal transformation of its participants.

\subsection{Objectives of the Study}

This study aimed to examine the effect of study circle on the moral attitudes of the psychology students at Samar State University.

Specifically, the study intended to determine the effect of the study circle on the moral attitudes of the students, identify the factors influencing the changes in the moral attitude of the students, and to develop an improved study circle material.

\section{Methodology}

\subsection{Research Design}

The study employed the triangulation approach as a blend of both quantitative and qualitative research designs. The quantitative design used a one sample-pretest-posttest experimental method, while the the qualitative designs used the methods of observation and focus group discussion. Triangulation is a strategy for increasing the validity of evaluation and findings in research (Seasmin \& Rahman, 2012), particularly as a way to avoid biases in the measurement, sampling, and procedure thereof.

\subsection{Variables and Data Gathering Instruments and Procedures}

Table 1. Correspondence table of the triangulation approach and main variables of the study

\begin{tabular}{|c|c|c|c|}
\hline Variable & $\begin{array}{c}\text { Questionnaire and } \\
\text { attitude scale }\end{array}$ & $\begin{array}{c}\text { Observation } \\
\text { checklist }\end{array}$ & $\begin{array}{c}\text { Focus group } \\
\text { discussion }\end{array}$ \\
\hline 1. Moral values and attitudes & $\square$ & $\square$ & $\square$ \\
\hline 2. Profile variates (age, sex, religion, income) & $\square$ & & \\
\hline 3. Attitudes toward the topics and quotations & $\square$ & $\square$ & $\square$ \\
\hline $\begin{array}{l}\text { 4. Perceptions toward the exercises, venue, } \\
\text { facilitator, general atmosphere, sessions }\end{array}$ & $\square$ & & $\square$ \\
\hline $\begin{array}{l}\text { 5. Attitudinal change (learning, living the life, } \\
\text { relationship with others }\end{array}$ & & & $\square$ \\
\hline $\begin{array}{l}\text { 6. Behavior during sessions (preparatory, during, } \\
\text { and end of session) }\end{array}$ & & $\square$ & \\
\hline $\begin{array}{l}\text { 7. Ability of participant to show potential as } \\
\text { facilitator }\end{array}$ & & $\square$ & \\
\hline 8. Attendance & & $\square$ & \\
\hline
\end{tabular}

Table 1 presents the main variables of the study and the corresponding instruments appropriate in measuring and 
generating the data thereof. Complete triangulation, a method with three instruments or components, was considered the most appropriate approach in dealing with the main variables of the study such as moral values and attitudes, and attitudes towards topics and quotations; while other variables were treated by either one or two instruments only.

This study primarily intended to look into both the overt and covert behavior of the individual who participated in study circle strategy. The overt behavior was treated using observation technique, and the covert one by the attitude scale and focus group discussion (FGD). Although the profile variates are overt-type, they were integrated in the first part of the attitude scale. On the other hand, data on attendance was taken separately during the study circle sessions.

\subsection{Respondents and Sampling Design}

The respondents were composed of 33 psychology students (see Table 2) from Samar State University-College of Arts and Sciences, Catbalogan City, Philippines. This selection method was used to avoid students becoming disoriented from their regular classes or vacant periods and, thus, avoiding unnecessary mood and predispositions change among them — a feeling which might occur and affect the results of the study.

Table 2. Respondents' profile

\begin{tabular}{|c|c|c|c|c|c|}
\hline Variable & & $f$ & $\%$ & Mean & $S D$ \\
\hline Age & & & & 18.5 & 2.44 \\
\hline \multirow[t]{2}{*}{ Sex } & Male & 4 & $12 \%$ & & \\
\hline & Female & 29 & $88 \%$ & & \\
\hline Family income* & & & & $11,603.03$ & $11,223.79$ \\
\hline \multirow[t]{3}{*}{ Religion } & R. Catholic & 31 & $94 \%$ & & \\
\hline & Born Again & 1 & $3 \%$ & & \\
\hline & $\mathrm{UCCP}$ & 1 & $3 \%$ & & \\
\hline \multirow[t]{6}{*}{ Occupation } & Gov. emp. & 8 & $24 \%$ & & \\
\hline & Farmer & 8 & $24 \%$ & & \\
\hline & Vendor & 5 & $15 \%$ & & \\
\hline & Var. Store & 2 & $6 \%$ & & \\
\hline & Carpenter & 2 & $6 \%$ & & \\
\hline & Others & 8 & $24 \%$ & & \\
\hline Total respondents & & 33 & $100 \%$ & & \\
\hline
\end{tabular}

\subsection{Validation of Instruments}

*Average per month in Philippine peso

The main instrument of the study was the questionnaire and moral attitude scale which contained 35 items on moral problems and situations. The respondents were allowed to answer it anonymously to express their true feelings or opinions. This instrument underwent validation and obtained a Spearman's rho $\left(r_{s}\right)$ value of 0.99 in the test-retest method of validation which therefore established the reliability of the instrument. The administration of the questionnaire and attitude scale was conducted by the researchers themselves. The other instruments and procedures were observation checklist and focus group discussion (FGD). These two instruments also underwent validation by experts and through pilot-testing.

\subsection{Gathering Qualitative Data}

The instruments and procedures utilized in collecting qualitative data were administered by trained field workers other than the researchers themselves. This arrangement was made so that researchers could avoid or mitigate occurrence of observer's bias. In order to obtain more objective data, the field workers were furnished a list of questions or guides to which the respondents may provide answers. In the case of observation checklist, the field workers checked on the indicators whether certain behaviors were manifested by the participants. The field workers also noted down the actions or behaviors that were otherwise not indicated in the observation checklist.

In the case of the FGD, field workers collected data based on the participants' discussions and written comments to topic items or questions. These data were processed by two experts through content analysis, in which responses were collated by topics, then were analyzed according to the commonality of thought and frequency, and summarized for inclusion in the report. Some unique or unusual thoughts were also retrieved and examined for further analysis. In general, the kind of comment bearing the highest frequency on a given topic would represent the common thought of the participants. The inter-rater reliability test on the output, using the Pearson's product moment correlation for ratio data, generated an $r$ value 0.907 with .000 level of significance, 
and thus, denoting the analysis as highly reliable.

\subsection{Study Circle Material and Method}

The material used in the study circle was a module entitled Lights of Wisdom which contained universal spiritual teachings gleaned from major religious scriptures of mankind. The module consisted of 20 pages containing passages and exercises themed along 7 spiritual values of betterment of the world (good deeds), truthfulness, kindly tongue, courtesy and politeness, justice, patience and perseverance, and prayer. The material itself was an improvement from the existing ones and validated for the purpose of the study.

The method of discussion adopted was the Ruhi Institute model (2009) which recommended 3 levels of understanding. The first level which is basic comprehension-is designed to understanding the meanings of the words and sentences. In here, the participants formulated questions whose answers were direct quotes from the texts as a way of gaining (either literal or symbolic) understanding of the meaning and context of various quotes. The second level related to the application of the texts to various real-world situations. This entailed examining simple daily acts (lying about one's taxes, cheating on an exam) in the light of certain spiritual principle of "truthfulness." The third level dealt with the implications of the various quotations on other aspects of social and spiritual values. Finally, the participants were encouraged to commit the passages to memory so that they could be remembered and applied in various situations.

\subsection{Statistical Instrumentation}

Statistical Package for Social Science (SPSS, Ver. 16.01 WIN RC, S/N 5057979) was used to treat all the quantitative data. The profile was calculated by frequency counts and the mean. In order to determine the degree of relationship or association between the attitude score and the profile variates, the test on correlation coefficient was computed by Spearman's rho for quantitative data. On the other hand, to find out the significant difference between the respondents' pretest and posttest scores on the attitude scale, the t-test on dependent samples was used.

\section{Results}

\subsection{Effect of Study Circle on the Moral Attitudes of Students}

Table 3. Differences in mean \& SD between pretest and posttest scores of respondents in moral attitude scale

\begin{tabular}{lcccc}
\hline \multicolumn{1}{c}{ Result } & Pretest & Posttest & Difference & Decision \\
\hline Mean & 3.50 & 4.28 & 0.78 & \\
SD & 0.29 & 0.26 & 0.28 & \\
Observation $(N)$ & 33 & 33 & 0.00 & \\
Df & 31 & 31 & 0.00 & \\
t-value & & & -13.489 & \\
\hline Sig. (2-tailed) & - & - & $0.000 * * *$ & ${\text { Reject } \mathrm{H}_{\mathrm{o}}}$ \\
\hline
\end{tabular}

$* * *$ Highly significant at $\alpha=0.05$

To test the null hypothesis $\left(\mathrm{H}_{\mathrm{o}}\right)$, that there is no significant difference between the scores on moral attitude of the students before and after participating in the study circle, the t-test (for dependent samples) function of the SPSS was used, and it was found that the participants' posttest score in the moral attitudes scale was significantly higher than their pretest score.

\subsection{Relationship between Moral Attitude and Profile Variates}

Table 4. Spearman Correlation Coefficient $\left(r_{s}\right)$ values and the levels of significance between the pretest-posttest differential score, and variates of attendance, age, sex, family income, occupation, and religion

\begin{tabular}{lcc}
\hline \multicolumn{1}{c}{ Variable } & \multicolumn{2}{c}{$\begin{array}{c}\text { Sig. } \\
\text { (2-tailed) }\end{array}$} \\
& $r_{s}$ value of Pretest-Posttest Difference & (at $\alpha=0.05)$ \\
\hline Attendance & 0.000 & 1.000 \\
Age & 0.055 & 0.769 \\
Sex & 0.189 & 0.310 \\
Family Income & -.060 & 0.750 \\
Occupation & -.102 & 0.584 \\
Religion & -.122 & 0.515 \\
\hline
\end{tabular}

To find out whether there was significant relationship between moral attitude scores of the participants and the 
profile variates, the researchers tested the null hypothesis $\left(\mathrm{H}_{\mathrm{o}}\right)$, and found no significant relationship between pretest-posttest differential score and the profile variates of attendance, age, sex, family income, occupation, and religion.

\subsection{Attendance at Study Circles}

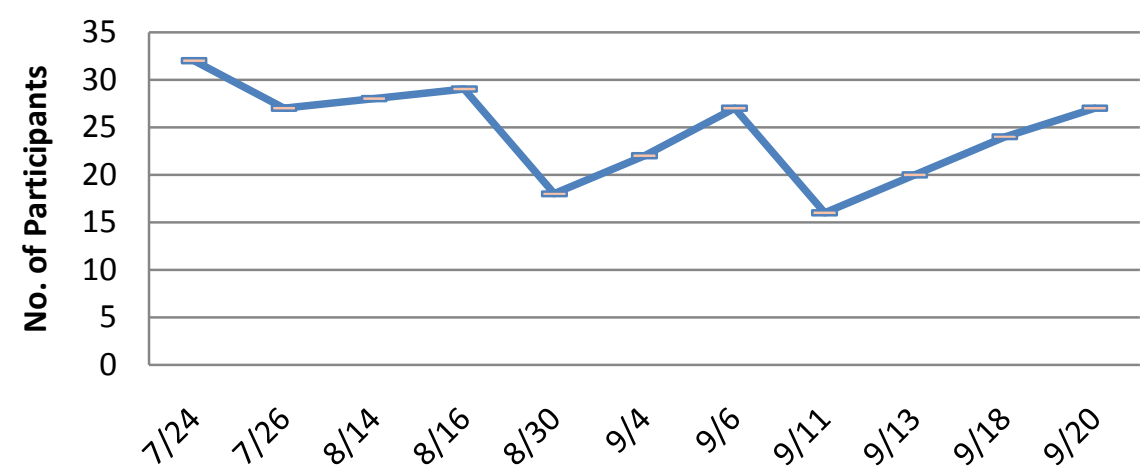

Figure 2. Attendance at study circle sessions

The days when attendance was infrequent among some participants were also the days associated with schedules for university intramural events, celebration of city fiesta, and faculty conference/seminars at the university.

\subsection{Participants' Involvement in Study Circle}

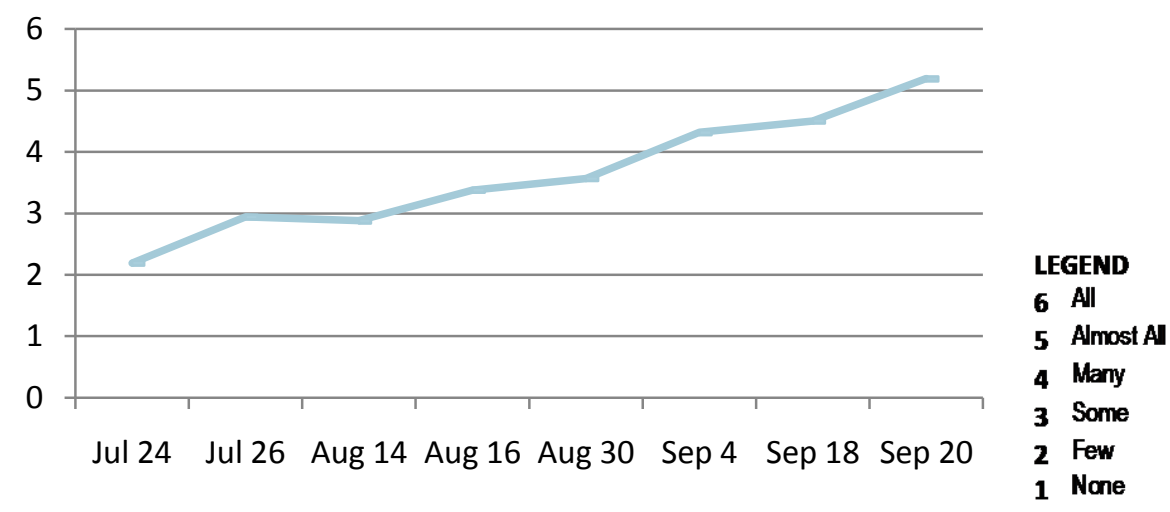

Figure 3. Participation in the study circle

From Figure 3, the development of participants' involvement in the study circle from "few" in number, at the start of the sessions, to "many" towards the end of the whole program shows the perceived changes in their attitude and behavior towards the following activities: preparing the venue, anticipating involvement, participating in reading the material, the Q\&A portion, in drawing implications, actively but courteously engaging in debate, participating in the recitation of passages, showing feelings of joy and excitement, and helping restore the room to original set-up, and showing ability to describe, compare, analyze, summarize, and restating ideas by the potential student-facilitator.

\subsection{Qualitative Data from the Respondents}

The following data were taken from the respondents' perception to the questionnaire in the FGD in the form of comments and remarks to given activities and elements of the study circle, namely: quotations, exercises, venue, facilitator, general atmosphere, topics liked, topics not liked; participants' change in terms knowledge, attitude, application in life, and in relation to others. Data generated revealed highly favorable comments from most of the respondents.

On the quotations, participants viewed them as well-organized, inspiring, enjoyable, and addictive. When asked for explanation, most of the participants replied that "we have understood and realized the importance of such values and that we can adapt the same for our self-adjustment or improvement." The following are the passages favored most by the participants - from the Bible: "And as ye would that men should do to you, do ye also to them likewise," (Luke 6:31); "A gentle answer turns away wrath, but a harsh word stirs up anger," (Proverbs 
15:1); "If you continue in my word you shall know the truth, and the truth shall set you free," (John 8: 31-32); and, "Be ye doers of the word of God, and not hearers only," (James 1:22).

From the Baha'i writings, participants' best choice were: "Backbiting quencheth the light of the heart and extinguisheth the life of the soul," (Baha'u'llah, Gleanings, 2004); "The betterment of the world can be accomplished through pure and goodly deeds, through commendable and seemly conduct," (Baha'u'llah, Cf. Shoghi Effendi, 2004); "Truthfulness is the foundation of all human virtues," (Abdu'l-Baha, 2004); "Courtesy is the prince of virtues," (Baha'u'llah, 2004); "Let your eye be chaste, your hand faithful, your tongue truthful, and your heart enlightened," (Baha'u'llah, Cf. Effendi, 2004); and "Breathe not the sins of others so long as thou art thyself a sinner," (Baha'u'llah, Hidden Words, 2004). The participants also were fond of this Buddhist writing: "The fragrance of the good does travel against the wind, and a good man perfumes the four quarters of the earth," (Buddhist, Dhammapada, 2012). The topic which they did not like was on "backbiting". This comment perhaps surfaced as most of the participants were close friends belonging to a "block" section of the class, and they felt it disgusting to badmouth their friends.

Most of the participants were identified as members of the Roman Catholic religion. When asked whether passages sourced from other religious scriptures might have mattered to them, the participants negatively replied, and said: "What's important is the meaning of the quotations to ourselves as humans, and not as Catholics."

On the exercises, the respondents observed them as employing both lower and higher-order thinking skills. "They were very challenging," they chorused. They also enjoyed memorizing the quotations, and felt it was necessary to "remember and make a quick reference to them when answering the exercises". Others also enjoyed giving reaction to certain issues and thus would let the occasion to start a lively debate.

The respondents considered the venue as peaceful and conducive to study circle activity. They also judged the facilitator to have shown very effective facilitation skills. When asked in what way he was effective, the participants said "he gave good ideas which were easy to understand along with some detailed discussions". The general atmosphere was democratic and participatory because they were allowed to air their personal feelings and thoughts even in the local dialect.

The participants felt there were some changes that occurred in their knowledge about the dynamics of good conduct. "We felt that we got more enlightened with what we have learned; it increased our knowledge." In their attitudes they felt as having been able to correct their own mistakes and, hence, to practice humility. In this aspect, the field workers noted that during the initial discussions and debates some students would pour out their respective opinions simultaneously without inhibitions to the extent of undermining the opinions of others, and they spoke rather raucously. It seemed that they were not aware of this and they just enjoyed exercising their academic freedom during the discussions. Later, their loud voices would turn mellow as they studied this passage: "A gentle answer turns away wrath, but a harsh word stirs up anger" (Proverbs 15:1); and another: "A kindly tongue is the lodestone of the hearts of men. It is the bread of the spirit, it clotheth the words with meaning. It is the fountain of the light of wisdom and understanding." (Baha'u'llah. Gleanings. p. 289). The facilitator himself felt it was no longer necessary to remind or scold the students, as they just said: "We felt we were straightened in our behavior from our understanding of the meaning of the passages."

As to their additional comments, most of the participants restated their answers in the previous items: that they learned in getting along with others; that the study circle was a great help, and the like. Before the termination of the sessions, a few participants asked if they could take home their copy of the study material, and explained "I would like to share it with my siblings at home." And so, of the 33 copies of the materials furnished to them, only 4 were left by the students at the venue. This means that $88 \%$ of them took home the material to either share it with others or to study them further by themselves and reflect on them.

\section{Discussion}

\subsection{Study Circle and Moral Attitudes}

The significantly higher score in moral attitudes of the participants in the posttest indicated the extent of effectiveness of the study circle in transforming moral attitudes and values of the participants. And based on observation, participants not only enjoyed and appreciated the process of their involvement in the study circle but also wanted to share the same experience with others. This transformative impact supports the findings of Chamiec-Case \& Sherr (2005) on integrating spirituality in the workplace, in promoting socially-significant values of citizenship and civic training (Brophy, 2011; Larsson, S. \& H. Nordvall, 2010), and in collectively finding solutions to local problems (McCoy, 2005).

\subsection{Moral Development}


Since none of the profile variates and other factors correlated with the participants' moral development, it can be inferred that nothing but the study circle itself and the study material were the only factors that caused the development of the participants' moral values and attitudes. Although attendance of some of the participants was rather erratic, it did not diminish their interest and enthusiasm in the lessons and activities. True enough, the decline in attendance was not actually caused by elements intrinsic in the students; it was rather caused by extrinsic factors such as the hiatuses of classes due to university intramural events, celebration of city fiesta, and faculty conference/seminars at the university. Usually when there were no classes many students declined in their momentum to attend immediate school activities and so with the study circles. The observation that was seen in the improvement of the number of participants from "few" to "almost all" indicated the unrelatedness of the level of attendance to one's moral development. Perhaps a minimum frequency of attendance could already allow some inculcation of some sense of spirituality and, hence, affect moral development in the individual.

\subsection{The Study Circle Material}

Since the materials used in this study covered certain universal principles known as spiritual teachings taken from some of the world's sacred scriptures, their impact on the participants cultivated an attitude of inclusiveness and deeper respect for such spiritual "truths" that cut across all these religious materials. It seems that this kind of attitude is important in eliminating any feeling of prejudice associated with religion or religious writings (Ressler \& Hodge, 2006; Danesh, 2010).

This study validates the principle that the use of spiritual precepts gleaned from religious scriptures as material for study circle enhances its effectiveness and relevance in the lives of people regardless of their backgrounds (Ruhi Institute, 2011). Through the study of religious and spiritual writings, the individual is able to establish an enduring foundation of his moral values, and abides his conduct by the word of God. Authentic morality (Hatcher, 1998) dictates that man's duty of loving his neighbor must be performed as a reflection of his love towards his divine and omnipotent Creator (Luke, 10:27). This duty ought not to be qualified or narrowed down by the limits of race, religion, gender or class (Chryssides, 1999: 250). If young people should develop attitudes based on religious and spiritual standards, they would undoubtedly lead virtuous and moral lives (Piazza, 2012) which is not only self-fulfilling but also socially rewarding (Butts, 1999). Such kind of values and attitudes may influence their roles and functions in society and, thus, contribute to social stability and the betterment of the world. (UN, 2007: p. 9).

\subsection{Development of Cognitive, Affective and Social Capacities}

Essentially, what factors or reasons can provide explanations to the significant impact of the study circle phenomenon? As a learning activity study circle cultivates the trinary characteristics intrinsic in the individual: the cognitive, affective, and social aspects. An individual's emotional response to a particular stimulus is preceded by rational processes and then acted upon through socialization, and vice versa. In this study the participating individual did enjoy studying the passages because he understood the significance of the values contained in them, and consequently he interacted and conversed with others to seek confirmation whether his understanding was correct or needing further group discussion. Such a reality is said to be reinforced by a healthy sense of belongingness (Durkheim, 1961; Summers, Beretvas, Svinicki \& Gorin, 2005) and cooperation (McCoy, 2005). This research has shown that study circle as a group learning activity engenders such intellectual, emotional and social benefits (Greenberg, Weissberg . . Elias, 2003); (Zins, Bloodworth, Weissberg et al., 2007). This is in contrast to vicarious methods of learning such as listening to lectures or moral preaching where, according to Cashin (1985), the learner tends to behave only as a passive student of a lecturer, as lectures are not well suited to higher levels of learning or critical thinking dispositions (Tiwari, Lai, So \& Yuen, 2006), neither in "influencing attitudes or values" (Cashin, 1985; Mulder, 2010). On the other hand, the dynamism of study circle cultivated spiritually-based moral attitudes and values amongst the participants. This shows that social processes of moral development affects emotional as well as intellectual functions of the individual. Thus, the process of moral development involves the holistic transformation of individual's cognitive, affective and social abilities - occurring not as separate events but rather as a composite integrated process.

\subsection{Conclusion}

Based on the theories of cognitive, affective and social potentials associated with the individual's participation in study circle on religious scripture-based material, the study showed a significant change in the participant's moral attitude. This finding was validated by both quantitative and qualitative data generated from the study.

From these findings and conclusion, the researchers recommended that the method of study circle should be adapted by educational institutions worldwide, though a few of them are already using it (Engineers Study Circle-India, 2005). Modules and supplementary materials may be developed in cognizance of the needs of 
users such as students, groups, institutions, and communities, with due considerations to their varied purposes (Brophy, 2001). Study circles may also be adapted in the workplace, either public or private, as enrichment for positive work values of the human resource, and as an encouragement towards achieving collective organizational objectives. In local communities, study circle maybe widely adapted as a method in improving the capacity of people-based organizations to promote local productivity through cooperativism (IDASA, 2005). For all these beneficial reasons, governments should provide support to the study circle movement by allocating adequate budget (Iowa Civil Rights Commission, 1997).

\section{Limitations of the study}

Due to the purposive nature of sampling of the respondents, the study did not infer representation of its immediate or larger population within or outside the university, and since the age of the respondents belonged to the teenage group, it also did not assume to have a similar outcome from other age groups. A survey method would better accomplish these representation requirements.

\section{Acknowledgment}

We are thankful to the following individuals and institutions for their help extended: Samar State University for providing fund for the research project, Prof. Anita Legatub for translation of the material into Tagalog for easier comprehension by the respondents, Dr. Florabelle B. Patosa for statistical analysis and expert opinion, Prof. Elma Sultan and Prof. Redentor Palencia for proof-reading the grammar and mechanics, Prof. Cresencia U. Gayamat and Prof. Rezy V. Mendaño for helping as research assistants, Dr. Felisa E. Gomba of the SSU-R\&D for giving so much encouragement and inspiration, Dean Meldrito B. Valles and Prof. Victoria C. Sabalza for the needed moral support, and the members of the family of the main author, especially to the late Mrs. Remedios S. Cabrales, for showing understanding and patience while the research was in progress.

\section{References}

Abdu'l-Baha. (2004). Compilations of compilations, Vol II, p. 338. http://reference. bahai.org/en/t/. p. 338. Accessed February 27, 2011.

Baha'u'llah (1990). Gleanings from the writings of Baha'u'llah. US Baha'i Publishing Trust. p. 265. Accessed February 27, 2011.

Baha'u'llah. In Shoghi Effendi (2004). Advent of divine justice. p. 24. http://reference.bahai.org/en/t/Accessed February 27, 2011.

Baha'u'llah. (2004). Hidden words. Arabic, 27. http://reference.bahai.org/en/t/ . Accessed February 27, 2011.

Baha'u'llah. (2004). Tablets of Baha'u'llah. p. 88. http://reference.bahai.org/en/t/. Accessed February 27, 2011.

Baker, A.C. et al. (2002). Conversational learning: An experiential approach to knowledge. Westport, Connecticut: Quorum Books. DOI: 10.1336/1567204988. http://www.google.com. ph/books?hl=. Accessed October 1, 2012.

Barski-Carrow, Barbara. (1998). Using study circles in the workplace as an educational method of facilitating readjustment after a traumatic life experience. Virginia Polytechnic Institute and State University. http://scholar.lib.vt. edu/theses/available/etd-4198-141633/). Accessed August 6, 2012.

Bible, King James Version. (1611). A reference edition with concordance. Manila: Philippine Bible Society.

Bjerkaker, Sturla. (2003). The Study circle - a method for learning, a tool for democracy. Paper for the FACE Annual Conference 2003. http:// www.face.stir.ac.uk/documents/ Paper109Bjerkader.pdf. Accessed June 26, 2013.

Boron, Carrie. (2013). Study circles-Case Studies. http://www.pgexchange.org/ index.php?option> . Accessed June 27, 2013.

Brennan, M., \& Brophy, M. (2010). Study circles and the dialogue to change program. In Australian Journal of Adult Learning, 50(2), 411-418. http://search.proquest.com/pqcentral/docview/. Accessed June 27, 2013.

Brevskolan. (1980). The study circle:A brief introduction. Stockholm: Brevskolan.

Brophy, M. (2001). The study circle:Participatory action research, with and for the unemployed. Ph.D. thesis, Victoria University, Australia. Retrieved <from studycircles.net.au/ Content/ category/theory; official URL: http://wallaby.vu.edu.au/ adt-VVUT/public/adt-VVUT2...>. Accessed March 27, 2012.

Brophy, M. (2011). Australia Study Circles Network. Retrieved from <http:// studycircles.net.au/ Content/dr-mark-brophy-director/> . Accessed October 27, 2011. 
Buddhist, Dhammapada. (2012). Sayings of the Buddha. Flowers-Canto IV, v. 54. http://www. theosociety.org/pasadena/dhamma/dham4.htm.

Butts, D. (1999). Spirituality at work: An overview. Journal of organizational change management, 12(4), 328-332. http://dx.doi.org/10.1108/09534819910282162 (Permanent URL).

Cashin, W. E. (1985). Improving Lectures. Evaluation and development: Idea Paper No. 14. September 1985. Manhattan, Kansas State University: Center for Faculty Evaluation and Development. http://www.theideacenter.org/sites/default/files/Idea_Paper_14.pdf. Accessed August 30. 2013.

Center For Ignatian Spirituality (Philippines). http://www. cisphil. org/. Accssed February 27, 2011.

Chamiec-Case, R., \& Michael, E. S. (2005). "Exploring how social work administrators integrate spirituality in the workplace". In Social Work and Christianity (2006) - nacsw.org. http://scholar.google.com. ph/scholar? $=1$. Accessed February 27, 2011).

Chryssides, G. D. (1999). Exploring new religions. Continuum International Publishing. ISBN 0-8264-5959-5. Accessed September 25, 2013.

Conrad and Hedin. (1977). Cited in Teaching for democratic citizenship. Edited by Ken Osborne. Accessed http://books.google.com.ph/books?id=5. Accessed October 31, 2012.

Danesh, R. (2010). Hegemony and revelation: A Baha'i perspective on world order. Religious studies and theology (on line). ISSN 1747-5414. http://dx.doi.org/10.1558/rsht.v29il.123.

Durkheim, E. (1961). Moral Education. New York: The Free Press. Cf. http://www. socpol.unimi.it/papers/2006-04-16Mariolina\%20Graziosi.pdf. Accessed July 1, 2013.

Effendi, S. (2004). Advent of divine justice. p. 24. http://reference.bahai.org/en/t/. Accessed February 27, 2011.

Engineers Study Circle-India. (2005). Bangalore - 560 025. http://www.engineersstudycircle. com/contactus.htm. Last updated May 2005. Accessed September 25, 2013.

Fraenkel, J. R. (1977). How to teach about values. Englewood Cliffs, NJ.: Prentice Hall, 1977.

Gibson, G. (1998). A Guide for Local Government on the Theory and Practice of Learning Circles.The Australian Centre for Regional and Local Government Studies, University of Canberra. Retrieved from <http://vuir.vu.edu.au/ 211/2/brophy.pdf>. June 27, 2013.

Greenberg, M. T., Weissberg, R. P., . . Elias, M. J. (2003). Enhancing school-based prevention and youth development through coordinated social, emotional, and academic learning. American Psychologist June-July 2003. American Psychological Association, Inc. Vol. 58, No. 6/7, 466-474 http://dx.doi.org/10.1037/0003-066X.58.6-7.466.

Hatcher, W. S. (1998). Love, power and justice: The dynamics of authentic morality. Wilmette, Illinois: Bahá'í Publishing Trust.

Hester, J. et al. (1997). Literature Study Circles in a Multicultural Classroom. In Language Arts. 74.1, Jan, 1997: 57-58. http://search.proquest.com/ pqcentral/docview/196869574/ 13EE9135EAA51 ABCA9E/6? accountid=141440. AccessedJune 27, 2013.

Hillyar, A., \& McDermid, J. (2000). Revolutionary women in Russia, 1870-1917: A study in collective biography. Manchester: Manchester University Press.

Hussain, I., \& Parveen, M. (2011). Identifying Reading Preferences of Secondary School Students. Creative Education, 2(5), 429-434. http://dx.doi.org/10.4236/ce.2011.25062.

IDASA-Institute for Democracy in South Africa. (2005). Evaluation report of the study circles project. Prepared by: Intuthuko Business and Development Solutions; Director: Lindiwe Nkutha. Retrieved from http://idasa.krazyboyz.co.za/media/uploads/outputs/files/final\%20report_.pdf.> p. 24. July 7, 2012.

Iowa Civil Rights Commission. (1997). Study Circles. Vol. 1, No. 1 April-May 1997. http://www.state.ia.us/government/crc/docs/studycirclesmarch.pdf

Jacobs, G. M., Lee, C., \& Ng. M. (1997). Co-operative learning in a thinking classroom. Paper presented at the International Conference on Thinking, Singapore. Cited in Creativity in a thinking classroom. Edited by Steve Padget.

Johnson, D., \& R. Johnson, R., \& Zaidman. (1984). Cited in Learning to cooperate, cooperating to learn. p.103. Edited by Robert Slavin, etal (1985).http://www.google.com.ph/books?hl= . Accessed October 29, 2012. 
Johnson, D. W., \& Roger, T. J. (2009). Social interdependence theory and cooperative learning: An educational psychology success story. http://dx.doi.org/10.3102/0013189x09339057

Keitgaard, R. (1985). Choosing Elites. New York: Basic Books. Cited in ASCD (1988). Moral education in the life of the school. http:// www.ascd.org/ASCD/pdf/journals/ ed_lead/el_198805_p4.pdf. Accessed October 1, 2012.

Kohlberg, L. (1976). Moral stages and moralization: The cognitive-developmental approach. Moral development and behavior, edited by T. Lickona. New York: Holt, Rinehart \& Winston.

Larsson, S., \& Nordvall, H. (2010). Study circles in Sweden: An overview with a bibliography of international literature. Linköping: Linköping University Electronic Press Available on Internet. URL: permanent link: http://urn.kb.se/resolve?urn=urn:nbn:se:ku:diva-57887.

Leighninger, M. (1996). Measuring the outcomes of community-wide study circle programs. In Public management (PM), 78(??), 39 - 41. PUB ID: 103-363-566 (Last edited on 2002/02/27 18:44:44 US/Mountain). http://www.getcited.org/pub/103363566. Accessed September 23, 2012.

Mazen, A. M., Jones, M. C., \& Sergenian, G. K. (2000). Transforming the class into a learning organization. Management Learning, 31(2), 147-161.

McCoy, M. L. (2005). Collaboration through Study circles. Journal of family \& consumer sciences, 97(1), 71-73. http://search.proquest.com/pqcentral/docview/218157462/13EE9135EAA51ABCA9E/4?accountid=141440. Accessed June 27, 2013.

Mulder, K. F. (2010). Don't preach. Practice! Value laden statements in academic sustainability education. International Journal of Sustainability in Higher Education, 11(1), 74-85. http://dx.doi.org/10.1108/14676371011010066 (Permanent URL).

Nau, J. M. (2012). Exploring learning processes within a collaborative study circle: Cultural-historical activity theory perspective on individual and social transformation. http://bahai-library.com/ nau_collaborative_ learning_processes. Accessed April 10, 2012.

Newmann, F. M., \& Rutter, R. A. (1983). The effects of high school community service prgrams on students' social development. Madison, WI: Wisconsin Center for Educational Research, University of Wisconsin. http://www.ydae.purdue.edu/lct/hbcu/documents/Effects. Accessed September 1, 2012.

Pax Romana Study Circle. (2008). Pax Romana Dialogue on "Catholic Social Teaching for a New Global Civilization". Washington, D.C. http:// www.catholic scholars forworkerjustice. org/prDialogue_events.html. Accessed September 23, 2012.

Piazza, J. (2012). "If You Love Me Keep My Commandments": Religiosity Increases Preference for Rule-Based Moral Arguments. International Journal for the Psychology of Religion, 22(4), 285-302. http://dx.doi.org/10.1080/10508619.2011.638598

Popenoe, D. (1995). Sociology 5th Edition. www.books.google.com

Raths, L., Harmin, M., \& Simon, S. (1978). Values and teaching. 2nd ed. Columbus, Ohio: Charles E. Merrill, 1978.

Ressler, L. E., \& Hodge, D. R. (2006). Religious discrimination in social work: Preliminary evidence. Journal of religion \& spirituality in social work: Social Thought, 24(4), 55-74.

Ruhi Institute. (2011). The Bahá'ís: Collaborative study for individual and social transformation. http://bahaikipedia.org/Study_circle. Accessed February 27, 2011.

Schaefer, U. (1983). The imperishable dominion: The Baha'i Faith and the future of mankind. Oxford: George Ronald.

Seasmin, S., \& Khan, F. R. (2012). Triangulation Research Method as the Tool of Social Science Research. BUP Journal, Volume 1, Issue 1, September 2012, ISSN: 2219-4851. http://www.bup.edu.bd/journal/154-163.pdf. Accessed August 23, 2013.

Slavin, R. et al. (1985) Learning to cooperate, cooperating to learn. Retrieved from http://www.google.com.ph/books?hl=en\&lr=\&id=R7_. October 29, 2012.

Summers, J. J., Beretvas, S. N., Svinicki, M. D., \& Gorin, J. S. (2005). Evaluating collaborative learning and community. The Journal of Experimental Education, 73(3), 165-188. Retrieved from http://search.proquest.com/docview/217665771?accountid=141440. 
Sotomayor, M, Dominguez, A, Pawlik, F. (2007). Building community capacity for health promotion in a Hispanic community. Prev Chronic Dis [serial online] 2007 Jan [date cited]. Available from: http:// www.cdc.gov/pcd/issues/2007/jan/06_0086.htm. Accessed March 29, 2013.

Study Circles for Divinity. (2001). Queensland, Australia: Divine Print Publishers and Sai Towers Publishing. http://members.ozemail.com.au/ ross88/page2.html. Accessed February 27, 2011.

Tiwari, A., Lai, P., So, M., \& Yuen, K. (2006). A comparison of the effects of problem-based learning and lecturing on the development of students' critical thinking. Medical education, 40(6), 547-554. http://dx.doi.org/10.1111/j.1365-2929.2006.02481.x. Accessed September 24, 2013.

United Nations Educational, Scientific and Cultural Organization. (UNESCO, 1999). Common framework for the ethics of the 21st century. September 1999. Paris: UNESCO. http://unesdoc.unesco.org/images/0011/001176/117622eo.pdf Accessed April 10, 2012.

UN. (2007). UN World Youth Report 2007 - Young People's Transition to Adulthood: Progress and Challenges'; New York: UN.). http://social.un.org/youthyear/docs/policy\%20guide.pdf. Accessed September 26, 2013.

Westergren, A., \& Gita, H. (2010). Do study circles and a nutritional care policy improve nutritional care in a short- and long-term perspective in special accommodations? Food \& Nutrition Research, 54, 5402. http://dx.doi.org/10.3402/fnr.v54i0.5402

Zins, J. E., Bloodworth, M. R., Weissberg, R. P., \& Walberg, H. J. (2007). The scientific base linking social and emotional learning to school success. Journal of educational and psychological consultation, 17(2-3), 191-210. http://www.tandfonline.com/doi/abs/10.1080/10474410701413145?journalCode=hepc20\#.UkDAdobi2vs.A ccessed September 24, 2013.

\section{$(\mathrm{cc}) \mathrm{Br}$}

This work is licensed under a Creative Commons Attribution 3.0 License. 